\title{
Performance analysis of Brazilian highways under concession through the capacity and level of service
}

\author{
Túlio Silveira Santos \\ Paulo Cezar Martins Ribeiro \\ Federal University of Rio de Janeiro \\ Transportation Engineering Program
}

\section{SUMMARY}

This paper proposes the development of a methodology to analyze the performance of highways under concession through the capacity and level of service, with special attention to Brazilian highways. The trajectory of transport infrastructure provision in Brazil and its performance assessment framework are mentioned, as well as an approach of the level of service concept and the Highway Capacity Manual (HCM). An inventory of the highway with the necessary data to the model is proposed. This database should incorporate information from multiple data sources and its use will be important for the processing and compilation of raw data in order to structure a full informational basis. Then, it is developed a method for segmentation of homogeneous road sections, as conceptualized by HCM, and proposed a way of level of service measurement. Finally, there are analysis of the use of $\mathrm{HCM}$ in some highways concession programs in Brazil.

\section{INTRODUCTION}

The main propose of this paper is the development of a methodology to analyze the performance of Brazilians highways under concession through the capacity and level of service. The road infrastructure sector affects directly the accessibility of the regions and the mobility of people and goods, contributing to access to work and income. The history of Brazilian road transport shows that road transport has been the most used in the transport matrix in Brazil since 1861 and has fulfilled the important task of contributing to the country's growth and to the integration of other modes of transport (CNT, 2014). From the seventies, the government sought partnership with the private sector to facilitate financing of public works. This association aimed at the allocation of technical, material and financial companies to implement works and services of public interest. Road concessions have been the most viable strategic alternative for the maintenance of roads at an appropriate level to traffic volumes and cover different forms of relationship between the state and the private sector with a view to developing infrastructure and public services. The concession model encompasses complete or part construction of any work of public interest, and their conservation, renovation, expansion or improvement.

Over the past decades have come up proposing different methods and models to assess the quality of service for road service. In the case of roads, there is the use of the Highway Capacity Manual (HCM), which is the main reference for the operational evaluation of concession highways. The HCM sets, whatever the type of infrastructure, six service levels designated by the letters "A" to "F", and "A" the best possible level of service and "F" the 
worst, corresponding to the unsteady flow condition and traffic congestion. HCM has become the reference in many countries for the assessment of capacity and level of service from the second edition of the manual (HRB 1965) and especially since 1990 (TRB, 2000) and his latest release, HCM 2010. Brazil also adopts HCM as a reference manual, but there is no agreement between the governing bodies and national regulatory agencies regarding the publication to use, as well as how to apply the concepts exposed by manual approaches.

\section{HIGHWAYS CONCESSIONS IN BRAZIL}

\subsection{Trajectory of transport infrastructure provision}

The trajectory of transport infrastructure provision is a reflection of the public sector organization (Prosdocimi, 2009). The development of public service provision, after a series of trial partnerships with the private sector, concentrated in the State through a government architecture focused on constant government planning, linked resources and structuring of municipalities or public companies strictly technical and bureaucratic. This model has been perpetuated until 1990, through concessions, transferred the management and financing to the private sector.

The government of Fernando Henrique Cardoso (1995-2003), the concept of concession, has been modified by creating new bodies responsible for transport infrastructure. Unlike privatization, property and public property concession remain public after the contract period (Nabhan, 2004). In the government of Lula (2003-2011), this program allowed the creation of partnerships between government and the private sector under the PPP model (PublicPrivate Partnerships) for investments, particularly in infrastructure.

According to Moreira (2014), there is a difference in the concepts of concessions in Brazil and the world, and the concept of PPP was born internationally with forms of PPP contract. In Brazil, there was, initially, the adoption of concession contracts in the classical model, and then called up PPP for the contract sponsored or subsidized by the state. Table 1 shows the procedures for granting and their financiers.

\begin{tabular}{|l|c|}
\hline \multicolumn{1}{|c|}{ Concession type } & Who pays? \\
\hline Common Concession & User \\
\hline \multirow{2}{*}{ Sponsored Concession } & User \\
\cline { 2 - 2 } & Granting Authority \\
\hline Administrative Concession & Granting Authority \\
\hline
\end{tabular}

Table 1 - Procedure for granting and its financiers (Neto, 2009)

From the table it is observed that the concessionaire's revenue comes from different sources according to the type of concession. While in a common concession the revenue comes directly from the toll rate, in an administrative concession the revenue is all passed on by the granting authority. In the case of sponsored concession, the revenue comes from the toll rate 
and the other part through a pecuniary compensation, which is the monthly amount to be paid by the grantor to the concessionaire according to performance indicators systematically applied the dealership.

Nowadays, public-private partnerships (PPPs) is one of the main instruments used by governments to invest in infrastructure in the country. In PPPs, the private sector participates with lending, investment, flexibility and managerial competence, while the public sector ensures the satisfaction of the interest of the population (PricewaterhouseCoopers, 2013).

\subsection{Performance Assessment Framework}

The concessionaire's performance evaluation is measured by using a performance indicator table that included performance indicators. According to Angelo (2005), the performance indicators are a way to analyze the verification of goals previously designed for strategic planning. These indicators are designed to measure the performance of the concessionaire, allowing the granting authority to monitor the quality of service, measure the monthly amount to be paid to the concessionaire (if applicable), and apply, as appropriate, the relevant sanctions. Typically, these indicators are divided into at least four areas (operational, environmental, social and financial) and each of these areas is made up of specific performance indicators weighing previously defined in the bidding documents. In the operating area, there is an indicator - Level of Service - that, through the HCM, determines the evaluation of road performance provided by the capacity and level of service.

\section{CAPACITY AND LEVEL OF SERVICE}

\subsection{Basic concepts}

A capacity analysis allows us to estimate the maximum flow rate that a certain highway section can accommodate, usually defined in terms of vehicles. The capacity of an infraestructure varies according to their geometrical characteristics, the variety of vehicles that use it and all the control measures applied to it (Hoel et al., 2011).

Closely associated with the concept of capacity is the level of service, which in turn is a qualitative measurement that describes the operating conditions of the traffic stream, such as speed and travel time, freedom to maneuver, traffic interruptions, comfort and convenience (TRB, 2000). The quality of the operation or the level of service of a particular infraestructure is a direct function of flow or level of use of the facility. In the highway concession, the level of service is used to ensure the quality of service provided to users.

The HCM sets, whatever the type of infrastructure, six levels of service expressed by the letters "A" to "F". The level of service "A" meets the free flow regime with very satisfactory traffic conditions. As traffic conditions are degrading, it is satisfying levels "B" and " $\mathrm{C}$ ", yet, a stable flow, with the level "D" assigned when the flow approaches instability. The level of service "E" represents flow conditions very close to the unstable regime, resulting from 
traffic charges are high with values close to capacity. The flow in high saturation regime, corresponding to congestion situations, is called the level of service " $F$ " (Costa and Macedo, 2008).

\subsection{Methodology for performance analysis of concession highways}

\subsubsection{Database Mounting}

For database composition used in this report, it is essential that information from multiple data sources are aggregated. The following list contains the most important information to be used and their sources:

- Registration aided by GPS, which must be produced from the field visit to the road.

- Photo database provided by Google.

- Information provided by managers of transport agencies, including: limits of homogeneous segments in study; location of the traffic analyzers and toll plazas; etc.

- Information provided by the operators of roads, including: volumetric scores of traffic analyzers and tolls operationalized by the concessionaire; location of access to the highway; the bases of Highway Police and Fire Department; the units of the concessionaire; and landmarks.

According to Hannon and Sulbaran (2008), the use of GPS as a data collection feature to transport planning studies is gradually becoming more common worldwide and is recommended for a large number of situations. Thus, the GPS equipment should be used to record the route taken in the form of tracks, with records of geographic position at intervals of one second, preferably. After the step of field visit, the tracks recorded by the GPS navigator should be imported and processed with the help of specific software (such as GTM TrackMaker Pro), in the form of geographic database and spreadsheets. Then, it starts to import the data into Excel environment, in order to concatenate the information collected, generate additional data and, finally, georeference the complete data set, in order to help further analysis of segments.

\subsubsection{Segmentation of homogeneous road sections}

For segmentation of homogeneous road sections, it is necessary to classify them as freeways, multilane highways or two-lane highways. This classification defines the method of HCM to be used in each case. The segments of a road differ along their length due to the discontinuity of physical and operational characteristics. Because of this variation, in traffic studies, the highway analyzed is divided in several homogeneous parts. This cartesian logic is advocated by HCM to facilitate analysis and set standards for evaluations.

The HCM considers the following items for segmentation of homogeneous road sections:

- Modification of the basic number of lanes of traffic along the highway;

- Change in central treatment along the highway (applicable in multilane highways)

- Changing the type of relief (level, rolling and mountainous); 
- Presence of traffic lights or signal flow interruption along the highway;

- Presence of additional lanes on upgrades or passing lanes;

- Change in traffic flow;

- Change in traffic flow in the opposite direction (applicable in two-lane highways);

- Percent of no-passing zones (applicable in two-lane highways)

- Changing of lane width;

- Changing the width of the free clearance in the left side of the road;

- Significant change in the access-point density;

- Change of speed limits;

- Presence of a bottleneck condition.

The HCM considers three types of reliefs in its methodology: level, rolling and mountainous. The relief type has an impact on vehicle performance, thereby altering the path capacity. The specific grade on highways causes reduction of speed of heavy vehicles, which reduces the highway capacity. Therefore, these grades should be treated separately. The analysis should consider the segments of upgrade and downgrade isolated and their combination in case of composite grade. The segments with lower inclination to $3 \%$ and longer than 800 meters, or inclination equal to or greater than $3 \%$ and longer than 400 meters should be regarded as specific ramps (Santos and Mourão, 2013; TRB, 2010).

\subsubsection{Level of service measurement}

In general, the level of service indicator is calculated as follows:

- Highway division into homogeneous segments;

- Data collection about speed;

- Survey of classified data from the traffic flow;

- Calculation of capacity and maximum flow according to the limits for each level of service; and

- Determining the level of service in each period of analysis based on the HCM procedures.

The data for measuring this indicator must be purchased through the installation of electronic equipment, in each homogeneous segment, able to obtain directly or indirectly the hourly traffic flow. The evaluation of this indicator is done by comparing the time the segment in analysis affects the traffic flow level corresponding to the level of service "D" and the established time-parameter by the contract management agency as the acceptable time when the segment should reach the level of service "D".

Following this reasoning, the design of a highway must admit a certain number of congested hours and the decision of what number is acceptable and essential for the adoption of volume design time. The DNER (1999) establishes that designing a highway under ideal conditions focuses on planning it with features to satisfy to the maximum hourly demand forecast for the project year. In such a situation, at any time of the year occur congestion. In return, the 
project would be uneconomical as the road would be oversized during other times of the year. When it has continuous hourly counts, which comprises a period of a complete year, one can determine the hourly volume to be used in the design of highway through the Nth order curve. This curve is in descending order of all volumes annual schedules, expressed as a percentage of Annual Average Daily Travel (AADT), designated as K-factor. The criterion of Nth order curve recommends that the value of $\mathrm{K}$ to be used in the project occurs by the passage in which the curve changes slope rapidly. In Brazil, it has adopted the project time volume equal the 50th hour in the places where there are permanent traffic analyzers.

\section{ANALYSIS OF THE USE OF HCM IN BRAZIL}

The lack of a highway capacity manual for Brazilian conditions refers to the direct use of HCM. However, the HCM points out that the procedures presented to American highways should be adapted to local conditions in each region.

\subsection{Common Concession}

According to Cunha and Setti (2009), the concessionaires of São Paulo state, under the supervision of the Transport Regulatory Agency of São Paulo State (ARTESP), provide periodic reports about the operational performance of highways. These companies must prevent any segment of highway exceeds the level of service "D" in more than 50 hours per year in accordance with the criteria established by HCM, throughout the concession period. If the operation in the level of service"D" exceeds the limit of 50 hours per year, the concessionaire should increase traffic capacity by investing in the expansion of road infrastructure.

On the other hand, ARTESP (2005) sets out specific rules for multilane highways and twolane highways. In the first case, the agency allows the use of HCM 2000, but makes an exception regarding the equivalence factors for heavy vehicles, so that even used the methodological procedures of HCM 2000, the equivalence factors to use should be defined in the version of 1994 because they are more compatible with the performance of the vehicle flow operating in concession highways, considering also that the third edition, the version 1994, was the current version of the HCM when bidding for concessions. In the second case, there is a strong object resistance to the use of HCM 2000 and 2010 by the agency, so it is just mentioned that the methodology of the HCM 2000 for analysis of level of service is totally different from the third edition of the HCM, version 1994, and the latter shall prevail.

\subsection{Sponsored Concession}

As stated previously, there is a strong resistance object to the use of the HCM 2000 and 2010 by Brazilian highway concessions. This also happens in the first public-private partnership in the country's road infrastructure area, the PPP of MG-050 highway, which is currently being tested by Minas Gerais state. It was decided that the HCM 1994 should be adopted as the standard to be used in studies with the caveat that it should consider the equivalence factors of trucks in specific grade studies, according to HCM 1985 and related to vehicles 
with a weight / power ratio of $300 \mathrm{lb} . / \mathrm{hp}$ (DER-MG, 2006).

The measurement of level of service was determined for the project time volume equal to 50th hour, so that the number of hours that the homogeneous segment can reach the level of service "E "or" $F$ " is below this value given the frequency of measurement, except at set periods of execution of works in which the level of service will inevitably be lower than the quality contracted.

\subsection{The issue of traffic trigger}

The performance of the infrastructure of a segment of highway will not be satisfactory to the extent that it presents flow conditions very close to the unstable regime, resulting from traffic charges are high with values near capacity or disposal in high saturation regime, corresponding to congestion situations. The volume of traffic that leads to such a situation is the traffic trigger, and there will be needed interventions of improvement works or increase capacity, such as deployment of passing lane or implementation of multilane on the segment in analysis.

This measure has been implemented recently in road concessions at the federal level, such as the highway BR-116, in Bahia state, located between Feira de Santana city and the border with Minas Gerais state. For this trigger model, which was used in Brazil in 2009, the concessionaire undertakes to do duplication of a segment only when the road reaches a preset volume of traffic.

\section{CONCLUSIONS}

According to what was mentioned in this paper, there is no agreement between the governing bodies and national regulatory agencies about what version of HCM method to use, as well as how to apply the concepts and conducts of the manual. Therefore, consistent rules for assessing the quality of road service in the concession programs should be promoted.

Following this reasoning, it is important to note that there are limitations of an adequate assessment of the level of service on highways concessions in the country. The use of methods of previous HCM to the latest version is a determination that imposes technical restrictions on the professionals involved with the operation of the highway, preventing the use of developments and new analytical possibilities introduced by the latest HCM 2010, especially related to the equivalency factors for heavy vehicles, directional analysis, passing lanes, among other criteria.

It is desirable that the level of service can be maintained appropriate over the period foreseen in the contract, regardless of the type of grant, demanding the concessionaires permanent monitoring of the performance of the infrastructure under management, taking into account the conditions effectively observed on highways. At the same time, it is necessary the adoption of the latest version of HCM method, not a mixture of the previous edition or the 
exclusive use of traffic trigger, and it is also desirable the adaptation of its parameters to Brazilian conditions.

\section{REFERENCES}

Ângelo; L. B. (2005) Indicadores de desempenho logístico. GELOG - UFSC 2005, Florianópolis, SC.

ARTESP (2005) Procedimento Prático Para Implantação de Faixas Adicionais. Empresa de Apoio e Gerenciamento [EAG-ARTESP], Setor de Operações, São Paulo, SP.

CNT (2014) Pesquisa CNT de rodovias 2014. CNT - SEST - SENAT, Brasília, DF.

Costa, A. H. P. e J. M. G. Macedo (2008) Manual de planejamento das acessibilidades e da gestão viária. Níveis de serviço em estradas e autoestradas. Comissão de Coordenação e Desenvolvimento Regional do Norte-CCDRN, Portugal.

Cunha, A. L. e J. R. Setti (2009) Fatores de equivalência para caminhões em rodovias de pista dupla. Anais do $6^{\circ}$ Congresso Brasileiro de Rodovias e Concessões - CBR\&C, Florianópolis, SC.

DER-MG (2006) Anexo VI: Diretrizes para apresentação da metodologia de execução. In: Concorrência para concessão de rodovias - Edital $n^{\circ}$ 070/06. DER MG, Belo Horizonte, MG.

DNER (1999) Manual de projeto geométrico de rodovias rurais. Departamento Nacional de Estradas de Rodagem, Diretoria de Desenvolvimento Tecnológico, Divisão de Capacitação Tecnológica. Rio de Janeiro, RJ.

Hannon, J. J. e T. Sulbaran (2008) Information technology for efficient project delivery, NCHRP Synthesis 385. Washington, D.C, USA: Transportation Research Board, The National Academies, 2008.

Hoel, L. A.; N. J. Garber e A. W. Sadek (2011) Engenharia de infraestrutura de transportes - Uma integração multimodal. Ed. Cengage Learning, São Paulo, SP.

HRB (1965) Highway Capacity Manual. Highway Research Board, Washington D.C., EUA.

Moreira, L. (2014) Análise dos diferentes contratos de concessão rodoviária e suas contabilizações. Editora CLA Cultura, São Paulo, SP.

Nabhan, F. M. (2004) Principais riscos envolvidos na decisão de investimentos em concessões rodoviárias no Brasil. Monografia, Programa de Educação Continuada, Escola Politécnica da Universidade de São Paulo, USP. São Paulo, SP.

Neto, M. Q. G. (2009) O papel do Verificador Independente como avaliador da performance do concessionário na primeira Parceria Público-Privada (PPP) do país no setor rodoviário: O caso da MG-050. II Congresso Consad de Gestão Pública - Painel 34: Boas práticas em compras e contratações públicas II. Brasília, DF.

PricewaterhouseCoopers (2013) Anuário $d a$ MG-050 2013. Available in: <http://www.transportes.mg.gov.br/downloads/Anuario_MG_050_13_compress.pdf $>$ Access: December, 2015.

Prosdocimi, D. O. B. (2009) Gestão por resultados na atividade regulatória: Análise da provisão de infraestrutura de transporte rodoviário. II Congresso Consad de Gestão Pública - Painel 58: Gestão da regulação, Brasília, DF.

Santos, T. S. e R. N. Mourão (2013) Estudo do nível de serviço da concessão sob parceria público-privada da rodovia MG-050, BR-265 e BR-491. Revista dos Transportes Públicos - ANTP, Ano 36, $3^{\circ}$ quadrimestre, n. 135, p. 49-59.

TRB (2000) Highway Capacity Manual 2000. Transportation Research Board, National Research Council, Washington D.C., EUA.

TRB (2010) Highway Capacity Manual 2010. Transportation Research Board, The National Academies, Washington D.C., EUA. 